\title{
EDITORIAL
}

\section{0 tips for intensive care management of transplanted liver patients}

\author{
Samir Jaber ${ }^{1,2^{*}}$ and Audrey De Jong ${ }^{1,2}$ \\ (c) 2019 Springer-Verlag GmbH Germany, part of Springer Nature
}

\begin{abstract}
Introduction
Among the 1600 liver transplants in Eurotransplant per year [1], most patients have an event-free and short ICU stay. However, mortality figures around $5 \%$ are still reported [2] and morbidity may also be substantial. Centers with higher case volume experience better outcomes, including in-hospital mortality and long-term survival, compared to centers with lower case volume [3]. The main purpose of ICU management after liver transplantation is, besides the general management that is applied after all major abdominal surgery, the prevention or early detection of hepatic complications and the problems related to immunosuppression. This article provides ten tips for ICU management of transplanted liver patients.
\end{abstract}

\section{Preoperative condition}

Many liver transplant patients have extensive comorbidity with potential major impact on the postoperative course: massive ascites, high output failure, cirrhotic cardiomyopathy (increased risk of pulmonary edema because of diastolic dysfunction, increased incidence of atrial fibrillation), hepatorenal syndrome, hyponatremia, hepatopulmonary syndrome, portopulmonary hypertension, encephalopathy, malnutrition or coagulopathy (which might be hypo- or hypercoagulability) [4]. The increasing incidence of coronary artery disease in liver transplant candidates mandates preoperative evaluation.

\footnotetext{
*Correspondence: s-jaber@chu-montpellier.fr

${ }^{1}$ Intensive Care Unit and Anaesthesiology Department, PhyMedExp, University of Montpellier Saint-Eloi Hospital, INSERM U1046, CNRS, UMR 9214, 80 avenue Augustin Fliche, 34295 Montpellier Cedex 5, France

Full author information is available at the end of the article
}

\section{Intraoperative events}

The surgical technique and intraoperative events (use of veno-venous bypass, difficult anastomosis of artery, portal vein or inferior vena cava, hemodynamic problems, bleeding) must be carefully recorded to understand the potential complications occurring after the liver transplantation.

\section{Hepatic complications}

The main hepatic complications are a poor primary graft or non-function (Fig. 1) [5]. In the early post-operative period daily ultrasound and biochemical monitoring are crucial to screen for vascular complications. Hepatic artery thrombosis is the most significant one and is often associated with graft failure and a large panel of biliary complications. Other complications include kinking of the inferior vena cava with lower body edema, thrombosis of the portal vein with acute ascites, acute rejection, bile duct problems, and recurrent ascites. When these complications occur, the ideal management is multidisciplinary, involving ICU physicians, surgeons, a gastroenterologist and/or an interventional radiologist. Since INR and factor $V$ are two highly efficient factors to assess liver function (together with lactate and consciousness), correction of coagulation should not be done unless there is evidence of bleeding [6]. In the case of suspicion of rejection, liver biopsy can be decided after multidisciplinary discussion. Computerized tomography scans should be performed early when complications are suspected. Cholangiography and magnetic resonance cholangiopancreatography are considered the most appropriate noninvasive imaging tools for evaluating biliary strictures. An acute respiratory failure in the early postoperative period is a surgical complication until proven otherwise. 


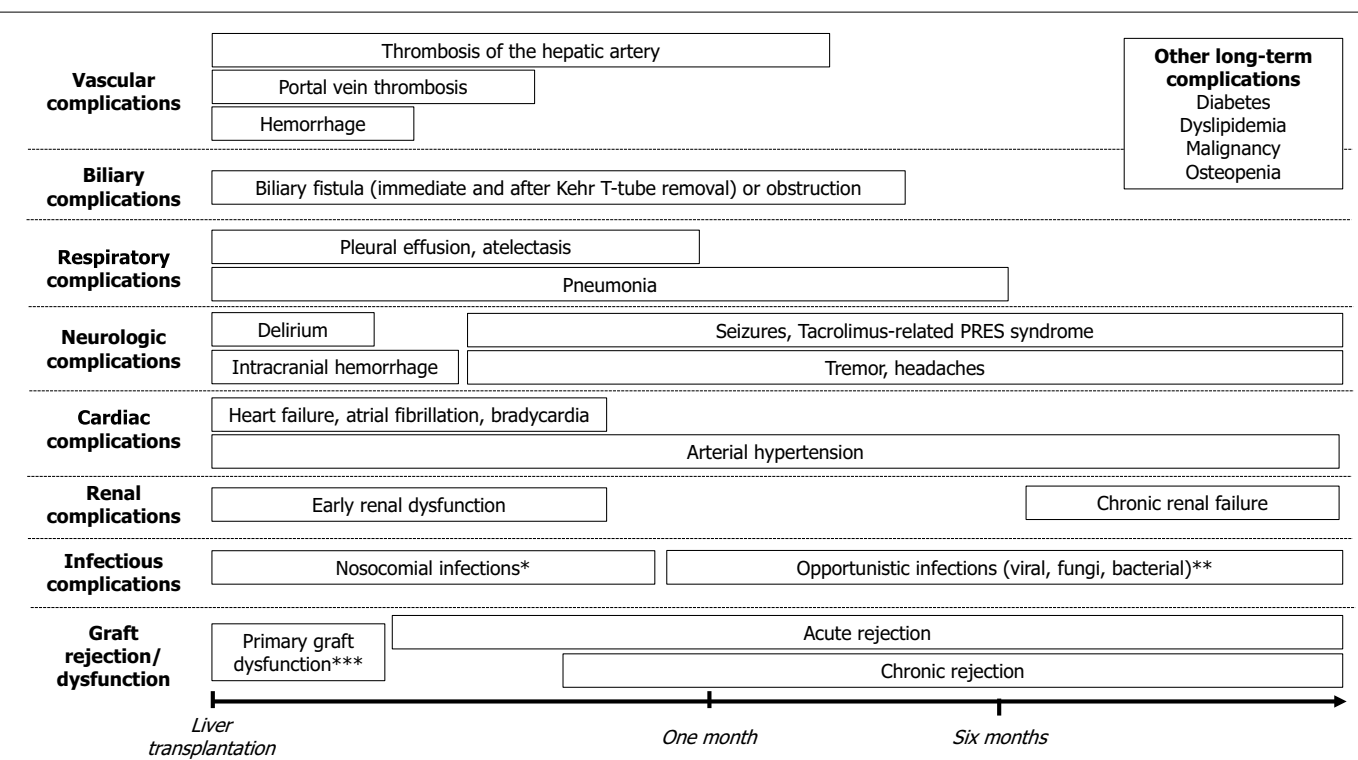

Fig. 1 Main complications following liver transplantation. *Include intra-hepatic or extra-hepatic abscess, cholangitis, pneumonia, urinary infection, and bacteremia. ${ }^{* *}$ Opportunistic infections: viral infections (especially cytomegalovirus, recurrence of herpes, Epstein-Barr and adeno-viruses). Viral infections are followed in decreasing order of frequency, by fungi (Pneumocystis carinii, Candida, Aspergillus, Cryptococcus), bacteria (Mycobacteria, Nocardia and Listeria) and parasites. ${ }^{* *}$ Include hyperacute rejection, primary non-function, preservation injury and small for size syndrome

\section{Cardiovascular management}

In the first hours following the liver transplantation, monitoring of fluid status is mandatory. Major postoperative hemorrhages are nowadays rare events. Crystalloids are the solutes of choice (being careful to avoid hyperchloremia), if necessary, in combination with albumin [7]. A frequent cause of postoperative hypovolemia is ongoing ascites production with associated hypoalbuminemia, especially in those with massive ascites before transplantation. Ascites fluid may leak to the pleural compartment. The optimal choice of vasopressor after liver transplantation remains to be established but recent evidence suggests superior kidney and patient outcome with terlipressin compared with norepinephrine in hepatorenal syndrome [8].

\section{Acute kidney injury}

AKI is a very common complication after liver transplantation [9]. The risk of post-operative acute kidney injury depends on the presence of preoperative hepatorenal syndrome, intra- and postoperative hemodynamics, renal congestion during inferior venous cava clamping (use of venovenous bypass or not), intraabdominal hypertension and toxicity of immunosuppressive therapy. In case of isolated increased urea levels, a GI bleeding should be suspected.

\section{Graft rejection prevention}

In general the risk of rejection in liver transplantation is lower than in other solid organ transplantations. Usual perioperative protocols of graft rejection prevention include steroids (in the absence of contra-indications), antimetabolites such as Mycophénolate mofétil and calcineurin inhibitors. The treatment should be adapted to the renal function, hepatic function and underlying immune state. In case of chronic or acute renal failure, anti IL2 receptor antibodies and higher doses of steroids can be considered with delay in the introduction of anticalcineurins until renal function improvement. In preoperative immunocompromised patients, immunosuppression may be further reduced. In case of clinical or biological signs of excessive immunosuppression (repeated infections, opportunistic infection, Cytomegalovirus reactivation) or septic shock, immunosuppression should be reduced until recovery of a better immune state.

\section{Infection prophylaxis and treatment}

The antibiotic and antifungal prophylaxis should be adapted to the patient's preoperative flora and immune status and to procedure-related events. Antifungal prophylaxis should be given in high-risk patients. Pneumonia is common among patients undergoing liver transplantation and is a major cause of morbidity. At the 
time of treatment initiation, an antimicrobial regimen usually proposed for late-onset pneumonia should be followed [10]. In case of suspicion of infection in a transplanted patient, whatever the delay after transplantation, broad-spectrum antibiotics should be introduced early, and then early readapted according to the results of the bacteriological samples.

\section{Nutrition management}

Malnutrition exists in more than $50 \%$ of liver transplanted patients and is associated with high morbidity. Prudent nutrition might be provided except in case of hemodynamic instability with high doses of vasopressors [11].

\section{Early weaning from mechanical ventilation and rehabilitation}

Sedation should be stopped very early in ICU. Benzodiazepines must be avoided per- and post-operatively; because of the liver metabolism of those drugs and their association with delirium. The SOS study [12] recently showed an improvement of prognosis of postoperative patients when sedation was stopped early. The early stop of sedation with subsequent earlier extubation could help to introduce an intensive early rehabilitation program, which is well tolerated and feasible for liver transplanted patients in the ICU [13]. In case of acute respiratory failure following extubation, after elimination of a surgical complication, noninvasive ventilation could decrease the reintubation rate [14]. Encephalopathy and abdominal distention or hepatopulmonary syndrome may delay the liberation from mechanical ventilation.

\section{Extracorporeal therapies}

In case of primary graft dysfunction, with persistent high bilirubin levels, plasmapheresis or molecular adsorbent recirculating system dialysis (MARS) might be used in getting through a difficult period [15], before an etiologic treatment or a re-transplantation.

\footnotetext{
Author details

${ }^{1}$ Intensive Care Unit and Anaesthesiology Department, PhyMedExp, University of Montpellier Saint-Eloi Hospital, INSERM U1046, CNRS, UMR 9214, 80 avenue Augustin Fliche, 34295 Montpellier Cedex 5, France. ${ }^{2}$ Anesthesia and Critical Care Department B, Centre Hospitalier Universitaire Montpellier, Saint Eloi Teaching Hospital, 34295 Montpellier Cedex 5, France.
}

\section{Compliance with ethical standards}

\section{Conflicts of interest}

Dr. Jaber reports receiving consulting fees from Drager, Xenios, and Fisher and Paykel.

\section{Ethical approval}

An approval by an ethics committee was not applicable.

\section{Publisher's Note}

Springer Nature remains neutral with regard to jurisdictional claims in published maps and institutional affiliations.

Received: 20 January 2019 Accepted: 21 February 2019

Published online: 28 February 2019

\section{References}

1. Jochmans I, van Rosmalen M, Pirenne J, Samuel U (2017) Adult Liver Allocation in Eurotransplant. Transplantation 101:1542-1550

2. Baganate F, Beal EW, Tumin D, Azoulay D, Mumtaz K, Black SM, Washburn K, Pawlik TM (2018) Early mortality after liver transplantation: defining the course and the cause. Surgery 164:694-704

3. Yoo S, Jang EJ, Yi NJ, Kim GH, Kim DH, Lee H, Jung CW, Ryu HG. (2018) Effect of institutional case volume on in-hospital mortality after living donor liver transplantation: Analysis of 7073 cases between 2007 and 2016 in Korea. Transplantation

4. Artru F, Louvet A, Ruiz I, Levesque E, Labreuche J, Ursic-Bedoya J, Lassailly G, Dharancy S, Boleslawski E, Lebuffe G, Kipnis E, Ichai P, Coilly A, De Martin E, Antonini TM, Vibert E, Jaber S, Herrerro A, Samuel D, Duhamel A, Pageaux GP, Mathurin P, Saliba F (2017) Liver transplantation in the most severely ill cirrhotic patients: a multicenter study in acute-on-chronic liver failure grade 3. J Hepatol 67:708-715

5. Jung B, Cisse M, Chanques G, Arsac E, Bismuth M, Panaro F, Perrigault PF, Souche B, Gallix B, Verzilli D, Delay JM, Navarro F, Pageaux GP, Jaber S (2011) Causes of early mortality after liver transplantation: a twenty-years single centre experience. Ann Fr Anesth Reanim 30:899-904

6. Dotsch TM, Dirkmann D, Bezinover D, Hartmann M, Treckmann JW, Paul A, Saner FH (2017) Assessment of standard laboratory tests and rotational thromboelastometry for the prediction of postoperative bleeding in liver transplantation. Br J Anaesth 119:402-410

7. Sang BH, Bang JY, Song JG, Hwang GS (2015) Hypoalbuminemia within two postoperative days is an independent risk factor for acute kidney injury following living donor liver transplantation: a propensity score analysis of 998 consecutive patients. Crit Care Med 43:2552-2561

8. Arora V, Maiwall R, Vijayaraghavan R, Jindal A, Saggere Muralikrishna S, Kumar G, Jain P, Sarin SK. (2018) Terlipressin is superior to noradrenaline in the management of acute kidney injury in acute on chronic liver failure. Hepatology (Baltimore, Md)

9. de Haan JE, Hoorn EJ, de Geus HRH (2017) Acute kidney injury after liver transplantation: recent insights and future perspectives. Best Pract Res Clin Gastroenterol 31:161-169

10. Weiss E, Dahmani S, Bert F, Janny S, Sommacale D, Dondero F, Francoz C, Belghiti J, Mantz J, Paugam-Burtz C (2010) Early-onset pneumonia after liver transplantation: microbiological findings and therapeutic consequences. Liver Transpl 16:1178-1185

11. Arabi YM, Casaer MP, Chapman M, Heyland DK, Ichai C, Marik PE, Martindale RG, McClave SA, Preiser JC, Reignier J, Rice TW, Van den Berghe G, van Zanten ARH, Weijs PJM (2017) The intensive care medicine research agenda in nutrition and metabolism. Intensive Care Med 43:1239-1256

12. Chanques G, Conseil M, Roger C, Constantin JM, Prades A, Carr J, Muller L, Jung B, Belafia F, Cisse M, Delay JM, de Jong A, Lefrant JY, Futier E, Mercier G, Molinari N, Jaber S (2017) Immediate interruption of sedation compared with usual sedation care in critically ill postoperative patients (SOSVentilation): a randomised, parallel-group clinical trial. Lancet Respirat Med 5:795-805

13. Maffei P, Wiramus S, Bensoussan L, Bienvenu L, Haddad E, Morange S, Fathallah M, Hardwigsen J, Viton JM, Le Treut YP, Albanese J, Gregoire E (2017) Intensive early rehabilitation in the intensive care unit for liver transplant recipients: a randomized controlled trial. Arch Phys Med Rehabil 98:1518-1525

14. Jaber S, Lescot T, Futier E, Paugam-Burtz C, Seguin P, Ferrandiere M, Lasocki S, Mimoz O, Hengy B, Sannini A, Pottecher J, Abback PS, Riu B, Belafia F, Constantin JM, Masseret E, Beaussier M, Verzilli D, De Jong A, Chanques G, Brochard L, Molinari N (2016) Effect of noninvasive ventilation on tracheal reintubation among patients with hypoxemic respiratory failure following abdominal surgery: a randomized clinical trial. Jama 315:1345-1353

15. Gerth HU, Pohlen M, Tholking G, Pavenstadt H, Brand M, Wilms C, HusingKabar A, Gorlich D, Kabar I, Schmidt HH (2017) Molecular adsorbent recirculating system (MARS) in acute liver injury and graft dysfunction: results from a case-control study. PloS One 12:e0175529 